\title{
Initial Resection of Potentially Viable Tissue is not Optimal Treatment for Grades II-IV Pancreatic Injuries
}

\author{
Dennis W. Vane $\cdot$ Armin Kiankhooy \\ Kennith H. Sartorelli · Jerrie L. Vane
}

Published online: 4 December 2008

(C) Société Internationale de Chirurgie 2008

\section{Erratum to: World J Surg}

\section{DOI 10.1007/s00268-008-9569-x}

In the above-mentioned article, published online on April 11,2008 , the following errors were not corrected:

1. Abstract: Conclusion section (line 5): the word "stint" should be "stent"
2. Patients and Methods (line 3): incorrect time frame " $<19$ years of age" should be " $<18$ years of age"

3. Results (line 1): incorrect time frame "January 2001 through December 2005" should be "January 2001 through January 2007"

4. Table 2: Incorrect summary of table: "8 patients with MPI" should be "9 Patients with MPI" and "4 patients with mPI" should be "5 patients with mPI"

The online version of the original article can be found under doi: 10.1007/s00268-008-9569-x.

D. W. Vane $(\square)$

Professor and Chair of Pediatric Surgery, Saint Louis University, Cardinal Glennon Children's Medical Center, 1465 South Grand Boulevard, St. Louis, Missouri 63104-1095, USA

e-mail: dvane@slu.edu

\section{A. Kiankhooy · K. H. Sartorelli · J. L. Vane} Division of Pediatric Surgery, Vermont Children's Hospital, University of Vermont College of Medicine, FAHC, 267 FL4, MC Campus, 111 Colchester Avenue, Burlington, VT 05401, USA 